\title{
COL18A1 Gene
}

National Cancer Institute

\section{Source}

National Cancer Institute. COL18A1 Gene. NCI Thesaurus. Code C24305.

This gene is involved in anti-angiogenic mediation. 